cliffs of the more resistant boulder clay below. This coalesces, and forms mud glaciers, and flows outwards upon the sands. The ends spread out, and assume the convex form usual with ordinary glaciers. The edges are crevassed longitudinally by being stretched open by the more rapid central currents, while the centre is well crevassed in the process of fanning out. The largest stream measured 60 feet across the fan, where it would be about 12 feet deep as far as exposed above the sands, for it sinks some distance into it, with a front of 6 feet.

Its slow advance causes the sand upon the shore in front to pucker into folds or convolutions, which crack, and large flakes or cakes of sand are pushed forwards in a slanting direction over those in front.

Every tide obliterates these marks and inequalities, but the distance the flanges of these flakes overlap between each tide indicates a movement of about 5 or 6 inches every twenty-four hours.

Here we have no fracture and regelation, or molecular disturbance in the exact sense of ice movement, yet the forms and currents are so similar, that with a slight covering of snow it would be difficult or impossible to detect any difference between mud and ordinary ice streams.

The convolutions and overlapping of the sands in front may not be without its value when studying the forms of the contorted drift, where folding is frequent, and the sliding of one bed over another apparent from the frequent repetition of the same bed in a vertical section. The slanting and concentric laminæ so frequently seen in our boulder clays, inclosing beds of stratified sands and gravels, may also, in some cases, be explained by the running down and overspreading of reconstructed boulder clay in a similar way to the mud-streams of Cromer, where it can be seen now in progress.

Sutton Coldfield.

WilliaM SHERWOOD.

\section{On Frozen Fish.}

DURING the last few weeks there have appeared in NATURE several letters containing extraordinary statements of the vitality of fish that have been frozen in ice. I have just found in a quaint old book - the "Anatomy of Sleep "- two further statements on this subject, and have therefore extracted them, thinking that they might prove of interest to readers of NATURE. The first statement is quoted by the author (Dr. Binns) from Franklin's "Journey to the Polar Seas," p. 248:- "The fish froze as fast as they were taken out of the net, and in a short time became a solid mass of ice; and, by a blow or two of the hatchet, were easily split open, when the intestines might be removed in one lump. If, in the completely frozen state, they were thawed before the fire, they recovered their animation. We have seen a carp recover so far as to hop about with much vigour, after it had been frozen six-and-thirty hours."

The second statement is quoted from Isaak Walton ("Complete Angler," p. 257), who "quotes Gessner for the fact of some large breams being put into a pond, which was frozen the next winter into one mass of ice, so that not one could be found, and all swimming about again when the pond thawed in the spring," which phenomenon seemed to Walton "a thing almost as incredible as the resurrection of an atheist."

Dr. Binns further quotes, from the Quarterly Review, a statement which goes to show that mosquitos have been frozen on to the surface of a lake in the evening, and thawed again by the morning sun into animation. 1 should like, therefore, to inquire, firstly, whether there are any records of cold-blooded vertebrate other than fish being thus frozen and recovered to life; secondly, whether any such thing is known of the invertebrates, such as Mollusca, Echinodermata, and Vermes; and thirdly, whether this reported freezing and subsequent recovery of insects can be confirmed? In connection with this last class, I ought perhaps to mention that caterpillars have, I believe, been reported to recover animation after being frozen.

March 27.

\section{F. H. PERRY COSTE.}

\section{On the Presence of a Sternum in Notidanus indicus.}

I HAVE just found that the omosternum of Notidanus, described by me in a recent number of NATURE (vol. xliii. p. I42), was originally described by my friend Prof. W. A. Haswell, of Sydney, who, in his paper "Studies on the Elasmobranch Skeleton" (Proc. Linn. Soc. N.S.W., vol. ix., 1884), has the following passage :-

"The shoulder-girdle is remarkable for the presence in the middle ventral line of a distinct four-sided lozenge-shaped carNO. I I 18 , vOL. $43 \hat{\jmath}$ tilage let in to the arch, as it were, in front. This is a condition which I have not observed or seen described in any other form it does not seem to occur either in Heplanchus cinereus or in Henanchus griseus. The intercepted cartilage is temptingly like a presternal, but the absence of such an element in any group nearer than the Amphibia seems to preclude this explanation."

Dr. Haswell gives no figure of the shoulder-girdle, but from the above description it would appear that the post-omosternum was absent in his specimen.

Dunedin, N.Z., January 27.

T. JEFFERY PARKER.

\section{Cackling of Hens.}

I HAVE recently published the following letter in the Field; but not having so far received any answer to the question which it presents, I should like to republish it in your columns, in order to ascertain whether any ornithologists to whom I have not already applied may have any information to give upon the subject.

Christ Church, Oxford, March 28. GEORGE J. ROMANES.

\section{Cackling of the Hens of Jungle Fozol.}

"Can any of your readers inform me whether or not the hens of the wild jungle fowl (Gallus bankiva) cackle after laying their eggs, in the manner of their domesticated descendants? I cannot find any literature upon the subject; but if wild hens do cackle in the jungle, surely somebody must have heard them. Mr. A. P. Bartlett informs me that, when confined in shrubberies of the Zoological Gardens, they do not cackle ; and, therefore, if nobody has ever heard them do so in a state of nature, we may fairly infer that the instinct is a product of domestication. If this should turn out to be the case, it would be a somewhat remarkable fact, and would, moreover, lead to the further question whether there are any parts of the world where domesticated poultry do not cackle."

\section{Wood's Holl Biological Lectures.}

A REVIEW of some lectures given by American naturalists at the Wood's Holl Laboratory appeared in your columns on March 19 (p. 457), signed with the initials "R. L." As there are statements made in that review for which I should much regret to be held responsible, I beg you to allow me to prevent any mistake $\mathrm{which}$ might arise from the similarity of the reviewer's initials to my own, and to state that the review was not written by me.

Bembridge, I. W., March 30.

E. RAY LANKESTER.

\section{New Comet.}

AT 9 p.m. on Monday, March 30, I picked up a bright, round nebulous object in Andromeda which I could not identify. I soon found it in rapid motion to the south, and its cometary nature was therefore placed beyond a doubt.

The position of the object is approximately R.A. r $4^{\circ}$. Decl. $43^{\circ}$ north, and its motion is carrying it quickly towards the sun, so that it becomes important it should be immediately observed for place and its orbit computed. It will probably disappear in two or three weeks.

At 4.30 on the morning of Tuesday, March $3 x$, the new comet was very distinctly visible, though the gibbous moon was shining brightly at the time.

At the end of the present week the comet will be near $\beta$ Andromedx, and a little sweeping in the region of this star will almost certainly reveal it, for it is too conspicuous to be overlooked even in a comparatively small telescope.

Bristol, March $3 \mathbf{I}$.

W. F. DenNing.

\section{THE ASTRONOMICAL CONGRESS.}

$\mathrm{O}^{\mathrm{u}}$ $\mathrm{R}$ readers will be glad to know that the invitations issued by Admiral Mouchez to the Directors of the various Observatories interested in prosecuting the photographic chart of the heavens have met with a very ready response. It is confidently expected that this Congress will be the last that will be found necessary, and before the astronomers have separated it is hoped that the scheme will have received its final shape, and that no important detail will have escaped attention.

The English contingent is represented by the Astronomer-Royal, Dr. Gill from the Cape of Good Hope, Mr. Plummer from Oxford, Captain Abney, and Mr. 